\title{
Benthic Macroinvertebrates along the Haraz Downstream in Southern Caspian Sea Basin: In Gradient of the Physicochemical Parameters
}

\author{
Amir Faraz Ghasemi ${ }^{1}$ and Morteza Kamali ${ }^{2}$ \\ ${ }^{1}$ Department of Marine Biology, Faculty of Marine Science and Oceanography, Khorramshahr University of Marine Science \\ and Technology, P.O. Box 64199-669, Khorramshahr, Khozestan, Iran \\ ${ }^{2}$ Department of Fisheries, Faculty of Natural Resources and Marine Science, Tarbiat Modares University, P.O. Box 46114-356, \\ Noor, Mazandaran, Iran \\ Correspondence should be addressed to Amir Faraz Ghasemi; faraz_ghasemi@yahoo.com
}

Received 4 June 2014; Accepted 10 September 2014; Published 8 October 2014

Academic Editor: Ajai K. Srivastav

Copyright (C) 2014 A. F. Ghasemi and M. Kamali. This is an open access article distributed under the Creative Commons Attribution License, which permits unrestricted use, distribution, and reproduction in any medium, provided the original work is properly cited.

The Haraz River is one of the most important rivers in the Caspian Sea basin. In order to investigate changes in the taxa abundance composition and feeding groups of the benthic macroinvertebrates, twelve-time sampling was carried out at nine stations along three different sites: (1) before, (2) into, and (3) after Amol City. Results showed impacts of anthropogenic activities caused by the urbanization and development on the occurrence of benthic macroinvertebrates taxa. Families, Hydropsychidae and Heptageniidae at site 1 and Tipulidae at sites 2 and 3, were significantly dominant. The feeding groups of gathering collectors and predators increased from site 1 to site 3, while the filtering collectors and scrapers decreased. Consequently, our data supported the use of the bioindicator concept for Haraz River. Some sensitive (Hydropsychidae, Heptageniidae, Baetidae, and Leuctridae) and tolerant families (Tipulidae and Naididae/Tubificidae) are introduced as potential bioindicators of clean and disturbed river's area, respectively.

\section{Introduction}

The benthic macroinvertebrates have long been used as indicators for biological monitoring programs. They play a key role in freshwater ecosystems in linking decomposers and producers food chains with top predators. They inhabited throughout the length of the river with large number of species, limited mobility, and relatively long lifespan, and so forth [1-6]. These characters offer a spectrum of responses to perturbations and, thus, their relative abundances have been used to make inferences about pollution loads such as organic pollution and nutrient enrichment $[1,3,7-$ 9]. The physicochemical analyses of the water quality are capable of detecting disturbance directly and only reflect the water quality at the moment of sampling. In contrast, the biological communities provide more faithful reflection of environmental conditions, since they are continually exposed to pollutants. Therefore, the study of biological communities as a bioindicator can reveal the impacts of intermittent or unrecorded pollution incidents $[1-3,9]$. Nonetheless, the use of macrobenthic invertebrates for bioindication purposes seems not to be popular or widespread in the Asian ecoregion. However, this technique provides a cheaper and worth method in river classification, as they are widely used in the Northern American and European ecoregions [8, 9]. In rivers of the southern Caspian Sea basin and especially Haraz River, information on the spatiotemporal variations in abundance composition of benthic communities is still extremely poor. The aims of our study are to (1) investigate the benthic macroinvertebrate assemblages and their functional feeding groups and (2) to analyze significant changes of their accounts among different sites along the urbanized part of Haraz River in relation to environmental conditions. Our results indicate the potential use of benthic macroinvertebrates for monitoring of Haraz River. Since the information on the benthic macroinvertebrates and their monitoring in 
the southern Caspian Sea basin is too limited, the present study in the Haraz River helps to develop further researches on these invertebrates and their biotope. Since the frequent supervision of the ecosystem integrity represents a priority task for water resource assessment, these results can help us to monitor and manage this river in the future.

\section{Materials and Methods}

The Haraz River is the second largest river in the southern Caspian Sea which originates from central Alborz mountains ranges and flows northwards through the flat plains in the Mazandaran province and discharges into the Caspian Sea. The River basin covers an area of $5100 \mathrm{~km}^{2}$ with $185 \mathrm{~km}$ length and average discharge of $940 \times 106 \mathrm{~m}^{3} /$ year. The width of river ranges from 50 to 500 meter and its slope increases to $13 \%$ at different locations [10]. In the upstream mountain part, because of the appropriate water there is an increasing number of rainbow trout farms. It seems that this region more or less affects by aquaculture effluent and river sand mining activities. In the downstream plain part, Haraz River passes through the heart of Amol City, a rapidly growing and heavily industrialized city with a population of over 200,000 and an area of $3185 \mathrm{~km}^{2}$. In this region, the water of Haraz River is used as a major source for agriculture activities and is heavily affected by untreated agricultural waste and domestic sewage.

The predominant substrates of sampling area include gravel and boulder rocks with leaf litter and sand only present in calm areas along the banks. The existence of sand mining in the upstream part of river causes the following: water appears much muddy and its color is brownish at all times. At each site, tree stations situated in 500 meter distance from each other. Site $1\left(36^{\circ} 25^{\prime} 58^{\prime \prime} \mathrm{N}\right.$ and $\left.52^{\circ} 21^{\prime} 04^{\prime \prime} \mathrm{E}\right)$ is situated in the entrance of city in a relatively undeveloped area characterized by no urbanization, houses, or residential communities. The water flowed faster and appeared much clearer than at the other sites. Although as a control site is not to be well conserved, as it is affected more or less by agricultural, river sand mining, construction of dike, and fish farming activities. Site $2\left(36^{\circ} 27^{\prime} 50^{\prime \prime} \mathrm{N}\right.$ and $\left.52^{\circ} 21^{\prime} 30^{\prime \prime} \mathrm{E}\right)$ is approximately $5 \mathrm{~km}$ from site 1 within Amol City limit in the city center (Dehkadeh Talaii Park). It is an urbanized area, as residential communities and houses are present in the immediate surroundings. It often has been channelized and dredged. Site $3\left(36^{\circ} 29^{\prime} 40^{\prime \prime} \mathrm{N}\right.$ and $\left.52^{\circ} 22^{\prime} 17^{\prime \prime} \mathrm{E}\right)$ is located in end of the city limit (Saba Shahr), approximately $5 \mathrm{~km}$ from site 2 where it is surrounded by agricultural lands. There is direct pumping of the untreated urban sewage to the river and garbage evacuation in the river bank. Water uptake from the river for agricultural use decreases the flow volume before the effluent discharge enters the river. The water is cloudier and smelly and contains a lot of suspended matter due to the sewage pollution. The substrate consists of rocks coated with black color of decomposing bacterial. There is abundant garbage and debris was deposited along the banks and within the stream and it seems that this site is the most disturbed one.
Sampling was carried out at nine stations in three different sites (three stations at each site): before, into, and after the Amol city along the Haraz River in 12 different time points in summer of 2007, 2008, and 2009 (Figure 1). Three replicates were collected using a $40 \times 40 \mathrm{~cm}$ Surber Sampler (with $0.360 \mathrm{~mm}$ mesh size) from main permanently flow parts and close to the vegetation at each station and were stored in separate plastic containers. In the laboratory, the contents from each container were gently sieved by a $0.5 \mathrm{~mm}$ mesh and the retained material was fixed in $4 \%$ buffered formalin. Then, organisms were separated and identified to the lowest possible level using a stereomicroscope. The water samples were collected at each site from the top $30 \mathrm{~cm}$ of the water column at the middle of the river by means of an acid-washed plastic bucket and rinsed with water from the site. Samples were stored in the bottles (for chemical analysis) and sterile glass flasks (for bacteriological analysis), cooled, transported to the laboratory, and processed within 12 hours of collection. For each sample, water quality parameters including dissolved oxygen (DO), fecal coliforms (FC), $\mathrm{pH}$, temperature $(T)$, 5-day biochemical oxygen demand $\left(\mathrm{BOD}_{5}\right)$, nitrate $\left(\mathrm{NO}_{3}\right)$, total phosphate $\left(\mathrm{PO}_{4}\right)$, turbidity, total solid (TS), and water flow (WF) were measured [11]. The quantification of these environmental variables is important since they can significantly influence the distribution and abundance of aquatic organisms in stream ecosystems [6].

Prior to the statistical analysis, data were tested for the normality (using Shapiro-Wilk) and the homogeneity of variance (using Levene's test). Significance of all tests was accepted at $P<0.05$. Whenever data were normal and homogeneous, one-way analysis of variance (ANOVA) was used to test the differences values. Tukey's test was used to assess the significant differences among the sites. Data from the three stations at each site (totaling 108 replicate samples) were plotted separately and the sites were compared. Nonmetric multidimensional scaling (nMDS) ordination based on Bray-Curtis similarity of species abundances was performed to visualize patterns of community similarities. These analyses were carried out using the SPSS version 16 and the PAST version 2.09. According to Merritt and Cummins [12] identified macroinvertebrates were grouped into five different feeding guilds that use the same resources in a similar morphological and/or behavioral fashion including gathering collectors, filtering collectors, predators, shredders, and scrapers. At each site, the percentages of the feeding guilds were calculated and shown in the graph.

\section{Results}

A summary description of the water quality parameters of the sampling sites is provided in Table 1. One-way ANOVA showed significant differences in means of dissolved oxygen, fecal coliforms, 5-day biochemical oxygen demand, nitrate, total phosphate, and water flow. There were no significant differences in means of $\mathrm{pH}$, temperature, turbidity, and total solid among sites.

As a whole of 324 collected replicate samples, a total of 8117 individuals with 11 orders, 18 families, and at 


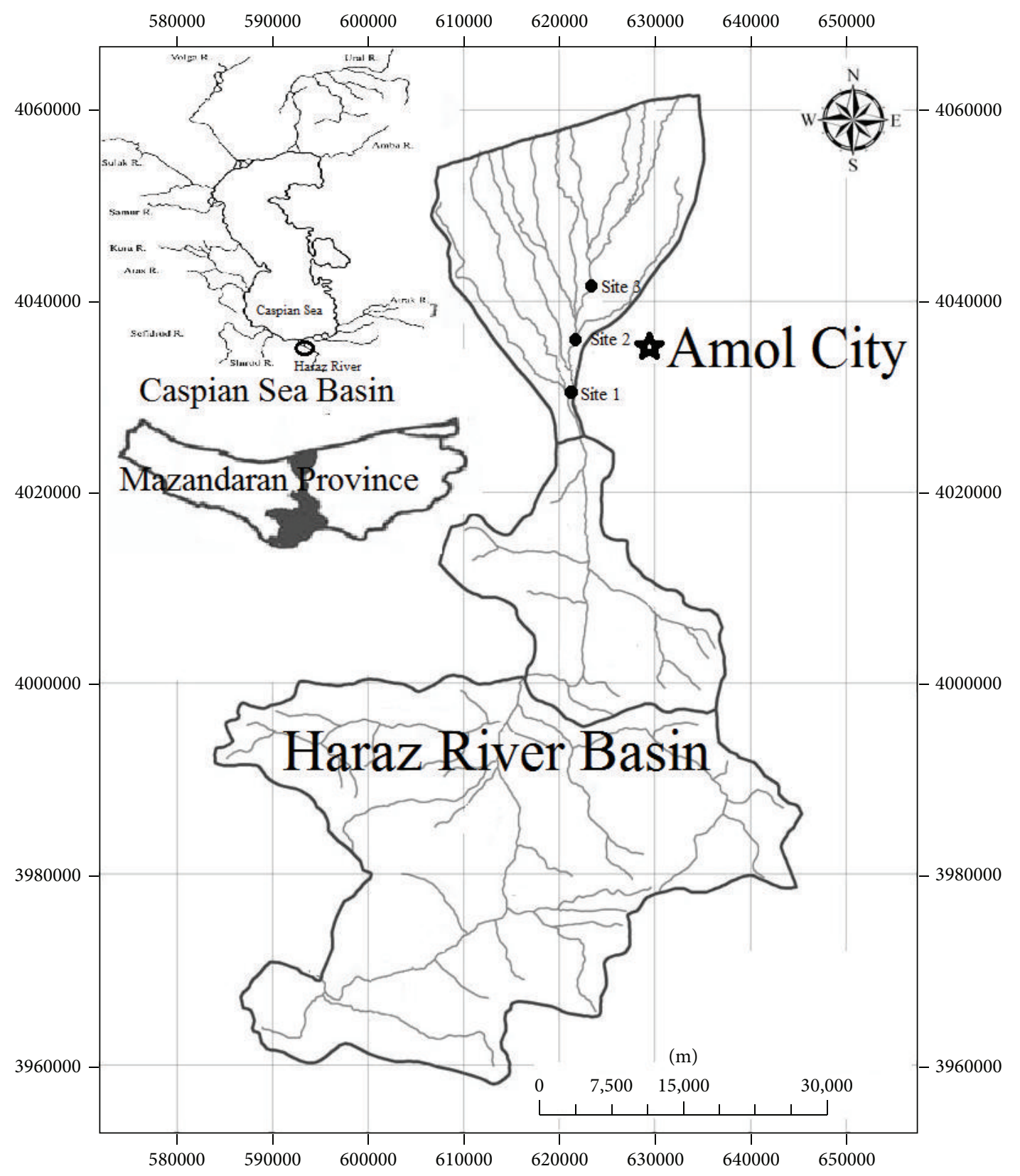

Figure 1: Location of sampling sites in the Haraz River, southern Caspian Sea basin.

least 20 genera belonging to insects (Coleoptera, Diptera, Ephemeroptera, Hemiptera, Odonata, Plecoptera, Prosobranchiata, and Trichoptera), crustaceans (Amphipoda), platyhelminthes (Turbellaria), and annelids (Oligochaeta) were identified (Table 2). The benthic macroinvertebrate community was dominated by insects throughout the sampling sites, including the families Hydropsychidae (37.99 \pm $29.86 \mathrm{ind} / \mathrm{m}^{2}$ ) and Chironomidae (36.77 $\left.\pm 10.42 \mathrm{ind} / \mathrm{m}^{2}\right)$, but the dominant structure differed among particular sites. The families, Hydropsychidae $\left(68.13 \pm 32.39 \mathrm{ind} / \mathrm{m}^{2}\right)$ and Heptageniidae $\left(42.69 \pm 16.31 \mathrm{ind} / \mathrm{m}^{2}\right)$ at site 1 and Tipulidae at sites $2\left(35.01 \pm 14.44 \mathrm{ind} / \mathrm{m}^{2}\right)$ and $3\left(45.65 \pm 19.11 \mathrm{ind} / \mathrm{m}^{2}\right)$, were dominant. The orders, Diptera with four families and five genera and Ephemeroptera with three families and four genera, had the highest richness. Except Gomphidae, Elmidae, and Gammaridae which did not collect at site 2, the other families were present at all sites. According Tukey test, total abundance was maximum at site $1\left(287.45 \pm 86.16 \mathrm{ind} / \mathrm{m}^{2}\right)$ and minimum at sites $2\left(205.84 \pm 14.83 \mathrm{ind} / \mathrm{m}^{2}\right)$ and $3(207.03 \pm$ $\left.60.60 \mathrm{ind} / \mathrm{m}^{2}\right)$. Abundances of Hydropsychidae, Heptageniidae, Baetidae, and Leuctridae were significantly decreased from site 1 to site 3, while Tipulidae and Naididae/Tubificidae increased. In Figure 2 nonmetric multidimensional scaling (nMDS) plot reflected the pattern of community structure similarities. As shown, stations were separated clearly based on the species abundances and physicochemical parameters. 
TABLE 1: Mean values ( \pm standard deviation) of the physicochemical parameters.

\begin{tabular}{lccc}
\hline & Site 1 & Site 2 & Site 3 \\
\hline Dissolved oxygen $(\mathrm{mg} / \mathrm{L})$ & $4.47 \pm 0.36^{\mathrm{a}}$ & $4.10 \pm 0.48^{\mathrm{ab}}$ & $3.84 \pm 0.41^{\mathrm{b}}$ \\
Fecal coliforms $(\mathrm{cfu} / 100 \mathrm{~mL})$ & $19.77 \pm 19.43^{\mathrm{a}}$ & $78.82 \pm 41.07^{\mathrm{b}}$ & $7.95 \pm 0.10^{\mathrm{a}}$ \\
$\mathrm{pH}$ & $8.02 \pm 0.09^{\mathrm{a}}$ & $23.21 \pm 7.84^{\mathrm{a}}$ & $7.82 \pm 0.17^{\mathrm{a}}$ \\
Temperature $\left({ }^{\circ} \mathrm{C}\right)$ & $22.69 \pm 5.05^{\mathrm{a}}$ & $35.69 \pm 19.01^{\mathrm{b}}$ & $24.08 \pm 6.30^{\mathrm{a}}$ \\
BOD5 $(\mathrm{mg} / \mathrm{L})$ & $14.15 \pm 7.22^{\mathrm{a}}$ & $3.59 \pm 1.22^{\mathrm{ab}}$ & $50.06 \pm 17.13^{\mathrm{b}}$ \\
Nitrate $(\mathrm{mg} / \mathrm{L})$ & $2.41 \pm 0.96^{\mathrm{a}}$ & $0.12 \pm 0.04^{\mathrm{b}}$ & $4.34 \pm 1.07^{\mathrm{b}}$ \\
Phosphate $(\mathrm{mg} / \mathrm{L})$ & $0.06 \pm 0.02^{\mathrm{a}}$ & $344.16 \pm 96.52^{\mathrm{a}}$ & $0.11 \pm 0.04^{\mathrm{b}}$ \\
Turbidity $(\mathrm{NTU})$ & $365.25 \pm 116.47^{\mathrm{a}}$ & $578.26 \pm 219.75^{\mathrm{a}}$ & $298.65 \pm 153.94^{\mathrm{a}}$ \\
Total solid $(\mathrm{mg} / \mathrm{L})$ & $614.40 \pm 231.61^{\mathrm{a}}$ & $4.49 \pm 1.73^{\mathrm{b}}$ & $564.76 \pm 341.02^{\mathrm{a}}$ \\
Water flow $\left(\mathrm{m}^{3} / \mathrm{s}\right)$ & $7.82 \pm 2.01^{\mathrm{a}}$ & & $0.67 \pm 2.19^{\mathrm{c}}$ \\
\hline
\end{tabular}

Letter case (superscript): variation among sites.

TABLE 2: Taxonomic composition and mean values \pm standard Deviation of abundance (individual $/ \mathrm{m}^{2}$ ) of the benthic macroinvertebrates.

\begin{tabular}{|c|c|c|c|c|c|c|}
\hline Order & Family & Genus & Site 1 & Site 2 & Site 3 & Total \\
\hline Amphipoda & Gammaridae & Gammarus & $7.00 \pm 7.09^{\mathrm{a}}$ & $0.00 \pm 0.00^{\mathrm{b}}$ & $6.55 \pm 0.87^{\mathrm{a}}$ & $4.52 \pm 5.11$ \\
\hline \multirow{2}{*}{ Coleoptera } & Elmidae & Narpus & $14.60 \pm 11.43^{\mathrm{a}}$ & $0.00 \pm 0.00^{\mathrm{b}}$ & $14.18 \pm 7.61^{\mathrm{a}}$ & $9.59 \pm 10.24$ \\
\hline & Dytiscidae & Deronectes & $8.89 \pm 1.93^{\mathrm{a}}$ & $12.47 \pm 9.53^{\mathrm{a}}$ & $9.18 \pm 6.59^{\mathrm{a}}$ & $10.18 \pm 6.65$ \\
\hline \multirow{5}{*}{ Diptera } & Chironomidae & Unknown & $39.29 \pm 10.21^{\mathrm{a}}$ & $28.49 \pm 6.90^{\mathrm{a}}$ & $42.53 \pm 9.18^{a}$ & $36.77 \pm 10.42$ \\
\hline & Simuliidae & Unknown & $13.52 \pm 13.09^{\mathrm{a}}$ & $20.07 \pm 19.38^{\mathrm{a}}$ & $1.52 \pm 1.65^{\mathrm{a}}$ & $11.70 \pm 15.06$ \\
\hline & Tabanidae & Unknown & $6.67 \pm 6.80^{\mathrm{a}}$ & $1.47 \pm 1.66^{\mathrm{a}}$ & $2.00 \pm 4.47^{\mathrm{a}}$ & $3.38 \pm 5.14$ \\
\hline & \multirow{2}{*}{ Tipulidae } & Dicranota & $9.50 \pm 10.16^{\mathrm{a}}$ & $25.00 \pm 25.34^{\mathrm{ab}}$ & $36.85 \pm 32.43^{\mathrm{b}}$ & $23.78 \pm 25.90$ \\
\hline & & Tipula & $2.00 \pm 2.83^{\mathrm{a}}$ & $10.01 \pm 3.53^{\mathrm{b}}$ & $8.80 \pm 5.98^{b}$ & $6.94 \pm 5.47$ \\
\hline \multirow{4}{*}{ Ephemeroptera } & Baetidae & Unknown & $13.52 \pm 13.09^{\mathrm{a}}$ & $13.52 \pm 13.09^{\mathrm{a}}$ & $3.70 \pm 3.68^{b}$ & $10.25 \pm 11.37$ \\
\hline & Caenidae & Caenis & $1.47 \pm 1.66^{\mathrm{a}}$ & $1.47 \pm 1.66^{\mathrm{a}}$ & $1.47 \pm 1.66^{\mathrm{a}}$ & $1.47 \pm 1.57$ \\
\hline & \multirow{2}{*}{ Heptageniidae } & Ecdyonurus & $19.18 \pm 14.16^{\mathrm{a}}$ & $14.01 \pm 8.99^{\mathrm{ab}}$ & $4.67 \pm 4.85^{\mathrm{b}}$ & $12.62 \pm 11.37$ \\
\hline & & Heptagenia & $23.51 \pm 18.46^{\mathrm{a}}$ & $1.47 \pm 1.66^{\mathrm{b}}$ & $2.80 \pm 2.74^{\mathrm{b}}$ & $9.26 \pm 14.57$ \\
\hline Hemiptera & Gerridae & Unknown & $4.33 \pm 4.68^{\mathrm{a}}$ & $9.18 \pm 4.34^{\mathrm{a}}$ & $2.00 \pm 4.47^{\mathrm{a}}$ & $5.17 \pm 5.25$ \\
\hline Odonata & Gomphidae & Unknown & $15.47 \pm 13.10^{\mathrm{a}}$ & $0.00 \pm 0.00^{\mathrm{a}}$ & $3.33 \pm 3.59^{\mathrm{a}}$ & $6.27 \pm 10.09$ \\
\hline Oligochaeta & Naididae/Tubificidae & Unknown & $4.33 \pm 6.16^{\mathrm{a}}$ & $8.67 \pm 8.69^{\mathrm{ab}}$ & $13.35 \pm 0.91^{\mathrm{b}}$ & $8.78 \pm 6.96$ \\
\hline Turbellaria & Planariidae & Phagocata & $11.00 \pm 11.05^{\mathrm{a}}$ & $16.67 \pm 16.72^{\mathrm{a}}$ & $15.47 \pm 14.82^{\mathrm{a}}$ & $14.38 \pm 13.88$ \\
\hline Plecoptera & Leuctridae & Unknown & $13.52 \pm 13.09^{\mathrm{a}}$ & $6.98 \pm 6.80^{\mathrm{ab}}$ & $1.52 \pm 1.65^{\mathrm{b}}$ & $7.34 \pm 9.56$ \\
\hline \multirow{2}{*}{ Prosobranchiata } & Valvatidae & Valvata & $7.00 \pm 7.28^{\mathrm{a}}$ & $4.80 \pm 2.01^{\mathrm{a}}$ & $8.68 \pm 4.16^{\mathrm{a}}$ & $6.83 \pm 4.99$ \\
\hline & Viviparidae & Unknown & $4.51 \pm 2.17^{\mathrm{a}}$ & $6.68 \pm 6.78^{a}$ & $7.47 \pm 4.50^{\mathrm{a}}$ & $6.22 \pm 4.79$ \\
\hline \multirow[t]{2}{*}{ Tricoptera } & Hydropsychidae & Unknown & $68.13 \pm 32.39^{\mathrm{a}}$ & $24.89 \pm 15.69^{\mathrm{ab}}$ & $20.97 \pm 8.83^{\mathrm{b}}$ & $37.99 \pm 29.86$ \\
\hline & Total & & $287.45 \pm 86.16^{\mathrm{a}}$ & $205.84 \pm 14.83^{b}$ & $207.03 \pm 60.60^{b}$ & $233.44 \pm 70.19$ \\
\hline
\end{tabular}

Letter case (superscript): significant variation among sites.

The feeding guilds compositions of the macroinvertebrate assemblages are shown in Figure 3. The gathering and filtering collectors were together dominant with about $60 \%$ of the total individuals at all sites. In general, the percentages of the gathering collectors and predators increased from site 1 to site 3, while the filtering collectors and scrapers decreased. The strong significant differences were observed just in the percentage means of gathering and filtering collectors between site 1 and 3 . There is no difference in percentage mean of shredders among sites.

\section{Discussion}

The results of physicochemical water quality parameters showed significant differences in means of the more causative organic pollution: dissolved oxygen, fecal coliforms, 5-day biochemical oxygen demand, and also of the more causative nutrient enrichment: nitrate, total phosphate, and also water flow. These values are reflected by an extensive decrease in water quality from site 1 to site 3 which are in agreement with results of Pejman et al. [13] and Nasirahmadi et al. [14] in the 


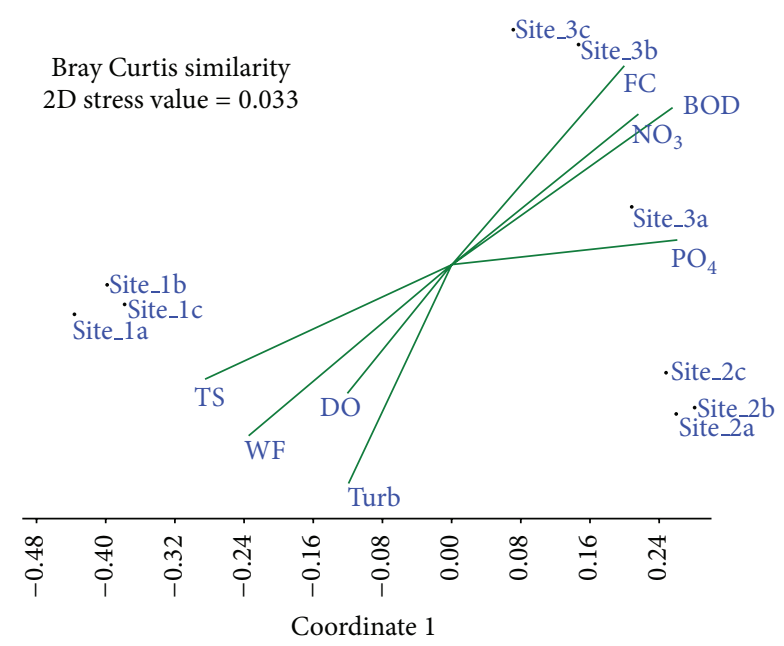

FIGURE 2: Nonmetric multidimensional scaling (nMDS) plot; pattern of the benthic community structure based on the species abundances and physicochemical parameters ( $a, b$, and c case letters after site number show stations of each site).

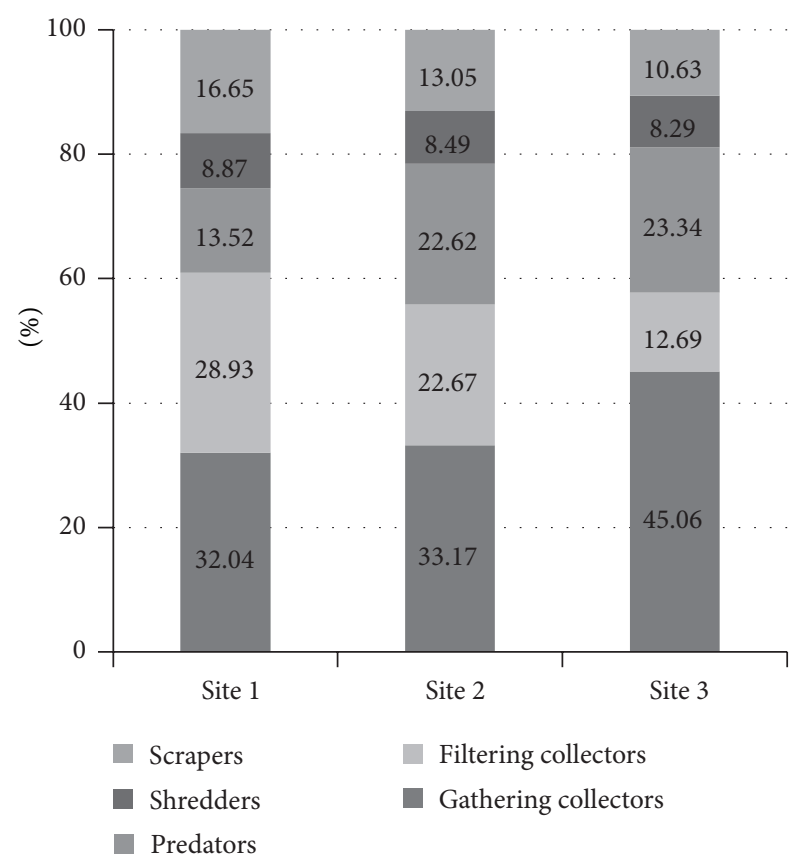

FIGURE 3: Feeding groups composition of the benthic macroinvertebrate community.

same area. These results that coupled with results of Khajuie et al. [15], Naderi Jolodar et al. [16], and Amirkolaie, [17] in the mountain upstream showed that water quality of plain downstream is much lower than upstream. There are several anthropogenic factors that may directly affect the water quality of this area. According to the high amount of fecal coliform bacteria at site 3 , the most important attributable factor could be the direct pumping of untreated urban sewage onto this part of river. Another important factor seems to be the discharge of the untreated waste water from agricultural lands with high amounts of pesticides and chemical fertilizer into the river. In addition, water uptake/exploitation for agricultural use, garbage evacuation to the river bank, dam construction, sand mining, and fish farming activities could have strong influences on the water quality. The impacts of these anthropogenic activities on the water quality have been previously documented in the most literature $[5,6,8,9,16$, 18]. As a result of river sand mining activities located before Amol city, there were no significant differences in means of turbidity and total solid between sites.

Overall, the benthic macroinvertebrates communities were dominated by insects especially Hydropsychidae and Chironomidae throughout sampling sites. The family Chironomidae was dominant or subdominant taxa at all sites (13\% at sites 1 and 2 and $20 \%$ at site 3). Due to their high diversity, the species of Chironomidae adapted to different habitat types from clean to highly disturbed, as they are common taxa of benthic communities [9, 19-24]. Hydropsychidae and Heptageniidae had the highest abundance at site 1 , and their abundance decreased to site 2 and then to site 3 . This could be related to the increase in pollutions loads and disturbances which was suggested before in southern Poland [18]. This reduction trend was also observed in abundance of Baetidae and Leuctridae. Generally, members of the orders Ephemeroptera, Plecoptera, and Trichoptera are considered to be sensitive to environmental stress and their establishment signified relatively clean conditions. Thus decrease in their abundance represents the lower water quality and higher degree of pollution, primarily organic pollution $[1,3,7,12]$. Conversely, the family Tipulidae increased from site 1 to site 3 and had the maximum abundance at this site. A similar pattern is obvious in Tubificidae Oligochaeta. These worms are known to be able to tolerate a variety of stressful and unfavorable conditions such as low DO concentrations and high organic pollution [25-27] caused by sewage outfall. Increasing abundance of gathering collectors Oligochaeta was evident in river stretches affected by anthropogenic organic pollution $[6,8,9,18,27,28]$. In general, it could be inferred that potential bioindicator taxa in undisturbed parts are typically Hydropsychidae, Heptageniidae, Baetidae, and Leuctridae, while in the polluted area they are Tipulidae and Naididae/Tubificidae.

Result of this study showed that there were significant differences in the total abundance of the benthic macroinvertebrates between site 1 and sites 2 and $3(P<0.05)$. A wide variety of biotic and abiotic factors could affect species abundances $[3,7]$ and so total abundance of community. The above-mentioned anthropogenic factors could be the reasons for the decrease in total abundance at sites 2 and 3. In comparison with the upstream mountain part of the Haraz River and the other rivers in the southern Caspian basin, the abundance of benthic community in the study area is too low and is about 10 times lower than those areas $[23,24,29]$. It seems that washing Macrofauna as a result of heavy rainfall and flood events is an important reason for the lower abundance in our study area. As we collected no specimens in five other samplings carried out in permanent flood conditions of winter, spring and autumn. 
Since feeding groups are sensitive to both natural and anthropogenic changes occurring along rivers, the abundance of each group is related to the status of environmental conditions and feeding resources [7, 12, 30]. Specialized feeders, such as scrapers and shredders, are the more sensitive organisms and are thought to be well represented in healthy streams [7]. Filter feeders are also thought to be sensitive to pollution in low-gradient streams [31]. Thus a decrease in the abundance of filtering collectors and scrapers groups from site 1 to site 3 was acceptable. But predicted response of shredders to increasing perturbation was not realized and there is no difference in percentage mean of shredders among sites. Many studies demonstrated significantly higher abundance of gathering collectors in river stretches affected by anthropogenic organic pollution and nutrient enrichment $[4,18,28]$ that is in agreement with results of our study.

\section{Conclusion}

Conclusively, the impacts of anthropogenic activities caused by the urbanization and development on the water quality and occurrence of benthic macroinvertebrates species were obvious and noticeable in almost clean and heavily polluted areas. Therefore, assemblage of certain macrobenthic species in unpolluted/polluted parts of Haraz River indicated that they could be used as potential pollution bioindicators. Since the data on the biology, ecology, taxonomy, and life histories of the benthic macroinvertebrates in rivers of the southern Caspian Sea basin and Haraz River is lacking, the present study is useful to develop further researches on these invertebrates and their biotope. This type of researches could provide valuable information in assessing and managing the ecological status of the rivers. Besides, more taxonomic work for the identification of organisms to species level should be done in order to get better results.

\section{Conflict of Interests}

The authors declare that there is no conflict of interests regarding the publication of this paper.

\section{Acknowledgments}

The authors gratefully acknowledge the contributions of Seyed Mahmoud Ghasempouri and Behbood Mohebby at the Tarbiat Modares University. Special thanks go to Tina Fartash Benamar and Rozhin Asghari Moghaddam who checked and improved the English.

\section{References}

[1] J. M. Hellawell, Biological Indicators of Freshwater Pollution and Environmental Management, Elsevier Applied Science, London, UK, 1986.

[2] J. L. Metcalfe, "Biological water quality assessment of running waters based on macroinvertebrate communities: history and present status in Europe," Environmental Pollution, vol. 60, no. 1-2, pp. 101-139, 1989.
[3] D. M. Rosenberg and V. H. Resh, Freshwater Biomonitoring and Benthic Macroinvertebrates, Chapman and Hall, New York, NY, USA, 1993.

[4] J. A. Camargo, A. Alonso, and M. De La Puente, "Multimetric assessment of nutrient enrichment in impounded rivers based on benthic macroinvertebrates," Environmental Monitoring and Assessment, vol. 96, no. 1-3, pp. 233-249, 2004.

[5] D. A. dos Santos, C. Molineri, M. C. Reynaga, and C. Basualdo, "Which index is the best to assess stream health?" Ecological Indicators, vol. 11, no. 2, pp. 582-589, 2011.

[6] J. A. Camargo, C. Gonzalo, and Á. Alonso, "Assessing trout farm pollution by biological metrics and indices based on aquatic macrophytes and benthic macroinvertebrates: a case study," Ecological Indicators, vol. 11, no. 3, pp. 911-917, 2011.

[7] M. T. Barbour, J. Gerritsen, B. D. Snyder, and J. B. Stribling, Rapid Bioassessment Protocols for Use in Streams and Wadeable Rivers: Periphyton, Benthic Macroinvertebrates and Fish, Office of Water, US Environmental Protection Agency, Washington, DC, USA, 2nd edition, 1999.

[8] M. Z. Azrina, C. K. Yap, A. Rahim Ismail, A. Ismail, and S. G. Tan, "Anthropogenic impacts on the distribution and biodiversity of benthic macroinvertebrates and water quality of the Langat River, Peninsular Malaysia," Ecotoxicology and Environmental Safety, vol. 64, no. 3, pp. 337-347, 2006.

[9] M. N. Varnosfaderany, E. Ebrahimi, N. Mirghaffary, and A. Safyanian, "Biological assessment of the Zayandeh Rud River, Iran, using benthic macroinvertebrates," Limnologica, vol. 40, no. 3, pp. 226-232, 2010.

[10] T. Nasrabadi, G. Nabi Bidhendi, A. Karbassi, and N. Mehrdadi, "Evaluating the efficiency of sediment metal pollution indices in interpreting the pollution of Haraz River sediments, southern Caspian Sea basin," Environmental Monitoring and Assessment, vol. 171, no. 1-4, pp. 395-410, 2010.

[11] APHA, Standard Methods for the Examination of Water and Waste Water, American Public Health Association, Washington, DC, USA, 1992.

[12] R. W. Merritt and K. W. Cummins, An Introduction to the Aquatic Insects of North America, Kendall/Hunt, Ames, Iowa, USA, 1978.

[13] A. H. Pejman, G. R. Nabi Bidhendi, A. R. Karbassi, N. Mehrdadi, and M. Esmaeili Bidhendi, "Evaluation of spatial and seasonal variations in surface water quality using multivariate statistical techniques," International Journal of Environmental Science and Technology, vol. 6, no. 3, pp. 467-476, 2009.

[14] K. Nasirahmadi, Z. Yousefi, and A. Tarassoli, "Zoning of water quality on Haraz river bases on national sanitation foundation water quality index," Journal of Mazandaran University of Medical Sciences, vol. 22, no. 92, pp. 64-71, 2012 (Persian).

[15] L. K. Khajuie, A. E. Sari, and S. M. Ghasempouri, "Assessment of Haraz River pollution from a rainbow trout farm," Iranian Journal of Marine Sciences, vol. 1, no. 3, pp. 27-34, 2002 (Persian).

[16] M. Naderi Jolodar, A. Esmaeili Sari, M. R. Ahmadi, S. J. Seyfabadi, and A. Abdoli, "The effects of Trout farm effluents on the water quality parameters of Haraz river," Environmental Science, vol. 4, no. 2, pp. 21-36, 2007 (Persian).

[17] A. K. Amirkolaie, "Environmental impact of nutrient discharged by aquaculture waste water on the Haraz River," Journal of Fisheries \& Aquatic Science, vol. 3, no. 5, pp. 275-279, 2008.

[18] I. Czerniawska-Kusza, "Comparing modified biological monitoring working party score system and several biological indices 
based on macroinvertebrates for water-quality assessment," Limnologica, vol. 35, no. 3, pp. 169-176, 2005.

[19] C. Lindegaard and K. P. Brodersen, "Distribution of Chironomidae (Diptera) in the river continuum," in Chironomids: From Genes to Ecosystems, P. Cranston, Ed., pp. 257-271, CSIRO, East Melbourne, Australia, 1994.

[20] L. S. Fore, J. R. Karr, and R. W. Wisseman, "Assessing invertebrate responses to human activities: evaluating alternative approaches," Journal of the North American Benthological Society, vol. 15, no. 2, pp. 212-231, 1996.

[21] G. Cognetti and F. Maltagliati, "Biodiversity and adaptive mechanisms in brackish water fauna," Marine Pollution Bulletin, vol. 40, no. 1, pp. 7-14, 2000.

[22] A. M. Pires, I. G. Cowx, and M. M. Coelho, "Benthic macroinvertebrate communities of intermittent streams in the middle reaches of the Guadiana Basin (Portugal)," Hydrobiologia, vol. 435, pp. 167-175, 2000.

[23] M. Kamali and A. E. Sari, "Bioassessment of Lasem River (Amol, Mazandaran Prov.) using macroinvertebrates community of structure," Journal of Biology Science, vol. 3, no. 1, pp. 5161, 2009 (Persian).

[24] M. Naderi Jolodar, A. Abdoli, M. K. Mirzakhani, and R. Sharifi Jolodar, "Benthic macroinvertebrates response in the Haraz River to the trout farms effluent," Iranian Journal of Natural Resources, vol. 64, no. 2, pp. 163-175, 2011 (Persian).

[25] R. O. Brinkhurst and C. R. Kennedy, "Studies on the biology of the tubificidae (Annelida, Oligochaeta) in a polluted stream," Journal of the Animal Ecology, vol. 34, no. 2, pp. 429-443, 1965.

[26] R. O. Brinkhurst, "The distribution of aquatic oligochaetes in Saginaw Bay, Lake Huron," Limnology and Oceanography, vol. 12, no. 1, pp. 137-143, 1967.

[27] M. T. Barbour, J. Gerritsen, G. E. Griffith et al., "A framework for biological criteria for Florida streams using benthic macroinvertebrates," Journal of the North American Benthological Society, vol. 15, no. 2, pp. 185-211, 1996.

[28] E. Dumnicka, "Upper Vistula River: response of aquatic communities to pollution and impoundment. X. Oligochaete taxocens," Polish Journal of Ecology, vol. 50, no. 2, pp. 237-247, 2002.

[29] M. Sharifinia, J. Imanpour, and A. Bozorgi, "Ecological assessment of the Tajan River using feeding groups of benthic macroinvertebrates and biotic indices," Iranian Journal of Applied Ecology, vol. 1, no. 1, pp. 80-95, 2012.

[30] R. L. Vannote, G. W. Minshall, K. W. Cummins, J. R. Sedell, and C. E. Cushing, "The river continuum concept," Canadian Journal of Fisheries and Aquatic Sciences, vol. 37, no. 1, pp. 130137, 1980.

[31] J. B. Wallace, J. R. Webster, and W. R. Woodall, “The role of filter feeders in flowing waters," Archiv für Hydrobiologie, vol. 79, pp. 506-532, 1977. 

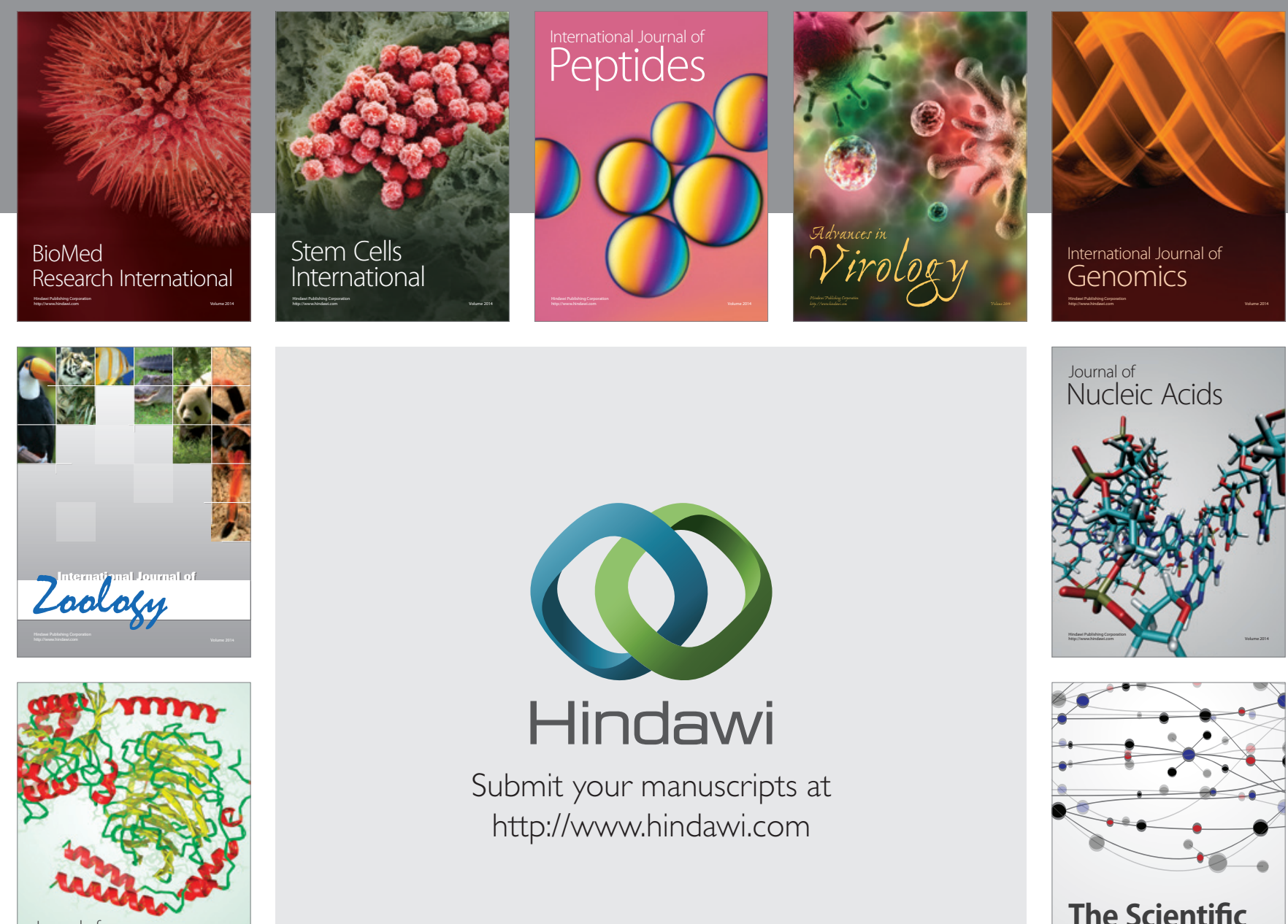

Submit your manuscripts at

http://www.hindawi.com

Journal of
Signal Transduction
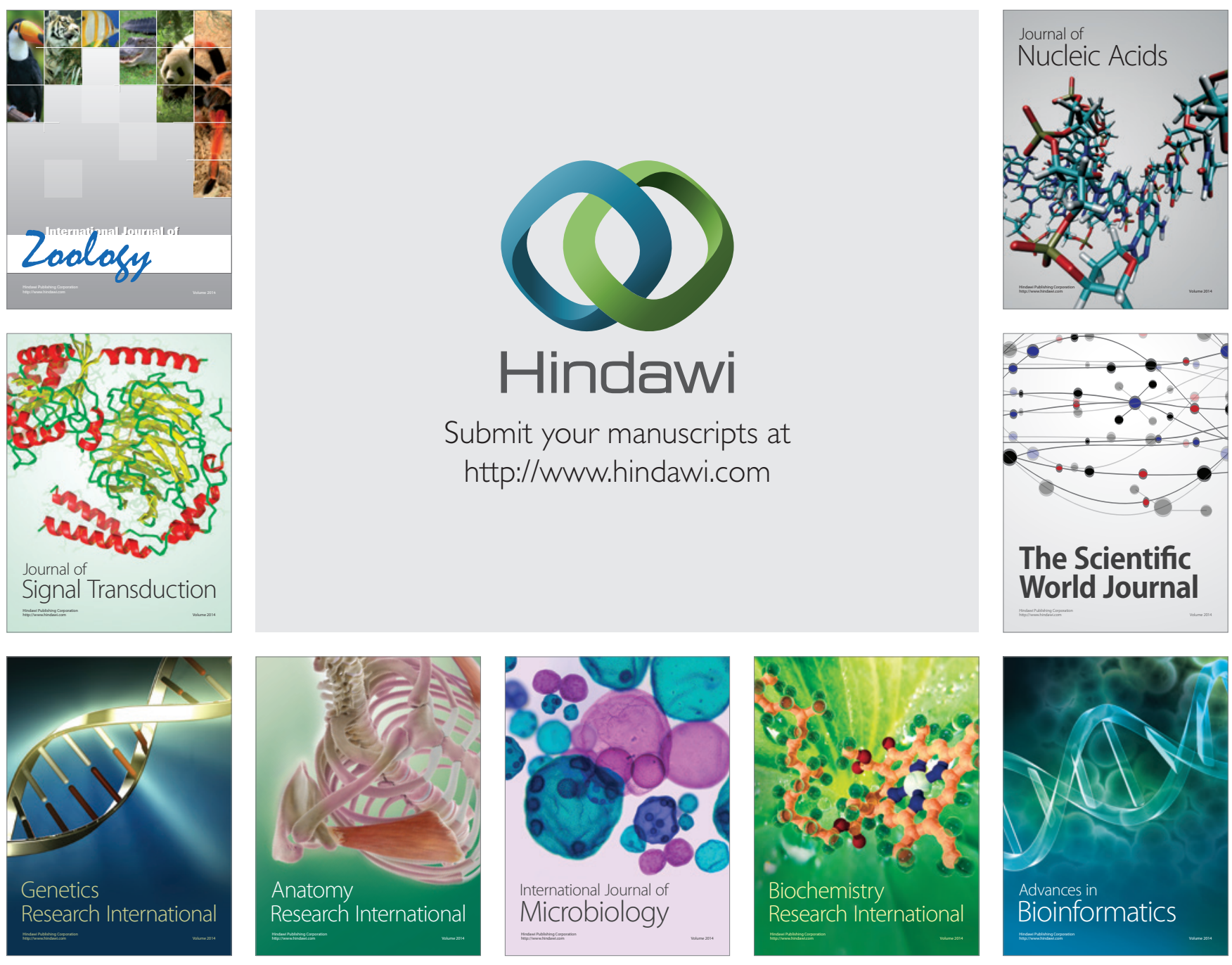

The Scientific World Journal
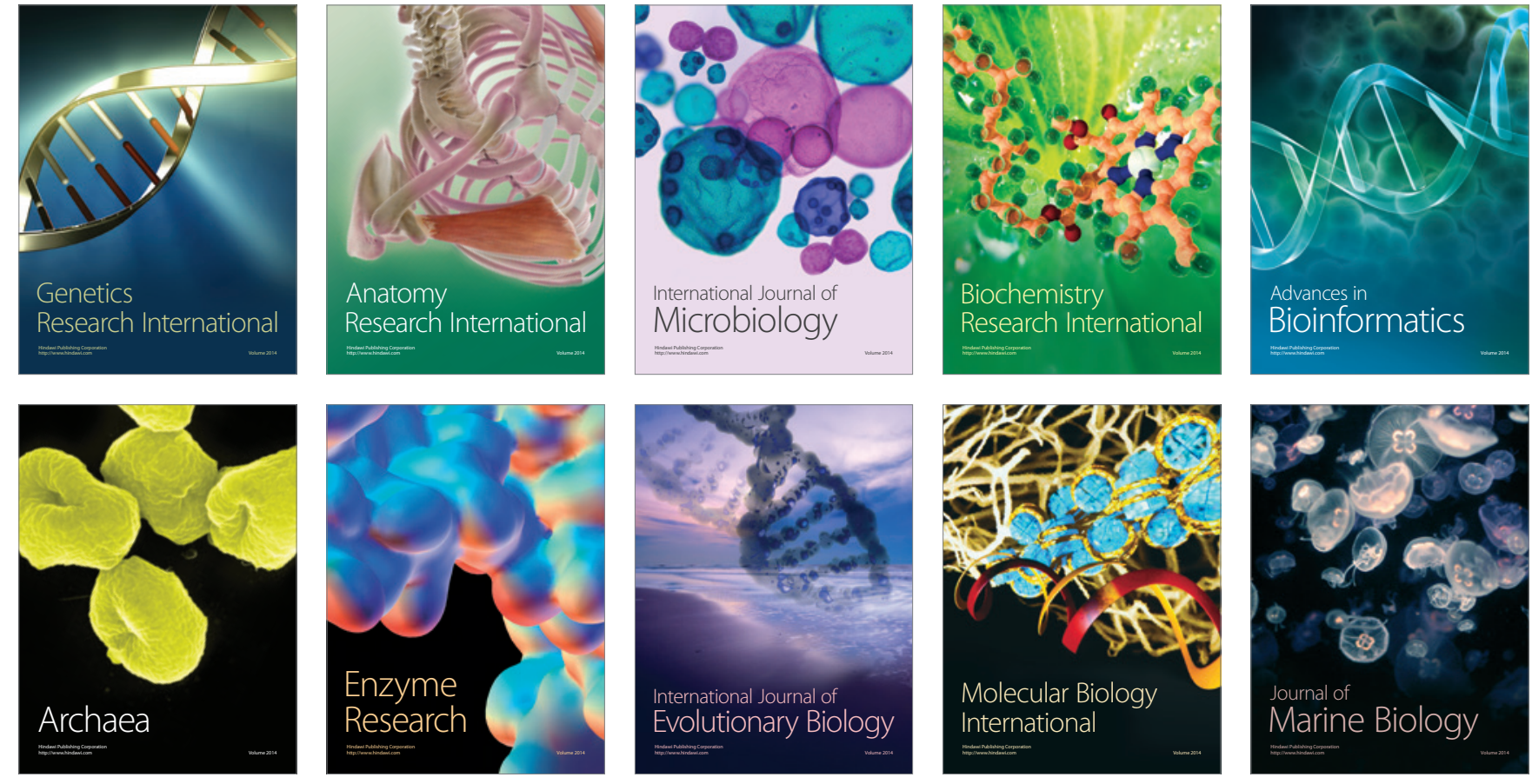